\title{
ECLETICA
}

www.scielo.br/eq

Volume 32, número 2, 2007

\section{Synthesis, characterization and thermal studies on solid state 3-methoxybenzoate of lighter trivalent lanthanides}

\author{
P. R. Dametto, A. B. Siqueira, C. T. Carvalho, M. Ionashiro*1 \\ Instituto de Química, UNESP, C. P. 355, CEP 14801 - 970, Araraquara, SP, Brazil. \\ *massaoi@iq.unesp.br
}

\begin{abstract}
Solid-state Ln -3-MeO-Bz compounds, where Ln stands for lighter trivalent lanthanides (La$\mathrm{Sm}$ ) and 3-methoxybenzoate, have been synthesized. Thermogravimetry (TG), differential scanning calorimetry (DSC), X-ray powder diffractometry, infrared spectroscopy, and complexometry were used to characterize and to study the thermal behaviour of these compounds. The results led to information concerning the composition, dehydration, polymorphic transformation, thermal behaviour and thermal decomposition of the synthesized compounds.
\end{abstract}

Keywords: Ligther lanthanides; 3-Methoxybenzoate; Characterization; Thermal behaviour.

\section{Introduction}

Benzoic acid and some of their derivatives have been used as conservant, catalyst precursors, in pharmaceutical industries, beyond other applications. The literature shows that the compounds of rare earth acid d-block elements with benzoic acid and some of its derivatives have been investigated in aqueous and in the solid state.

In aqueous solutions, the works reported the thermodynamics of complexation; spectroscopy study; influence of $\mathrm{pH}$; surfactant and synergic agent on the luminescent properties; crystal structure, photophysical and magnetic properties [1-5].

In the solid state, the works reported the thermal and spectral behaviour on solid compounds of benzoates and its derivatives with rare earth elements [6-12]; the vibrational and electronic spectroscopy study of lanthanides and effect of sodium on the aromatic system of benzoic acid [13-14]; the reaction of divalent cooper, cobalt and nickel with 3-hydroxy-4-methoxy and 3methoxy-4-hydroxybenzoic acid and a structure for these compounds has been proposed on the basis of spectroscopy and thermogravimetric data [15]. The thermal decomposition of thorium salts of benzoic acid 4-methoxybenzoic acids in air atmosphere [16] and thermal behaviour of solid state 4-methoxy; 3-methoxy; 2-methoxybenzoates and benzoate of some bivalent transition metal ions have also been described [17-20].

In this work the 3-methoxybenzoates of lighter trivalent lanthanides (La-Sm) were synthesized and characterized by X-ray powder diffractometry, infrared spectroscopy, thermogravimetry (TG), differential scanning calorimetry (DSC) and complexometry.

\section{Experimental details}

The 3-methoxybenzoic acid (3-MeO-HBz) $99 \%$ was obtained from Aldrich. Aqueous solution of $\mathrm{Na}-3-\mathrm{MeO}-\mathrm{Bz} 0.1 \mathrm{~mol} \mathrm{~L}^{-1}$ was prepared from aqueous $3-\mathrm{MeO}-\mathrm{HBz}$ suspension by adding sodium hydroxide solution $2.5 \mathrm{~mol} \mathrm{~L}^{-1}$ up to near total neutralization, followed by $\mathrm{NaOH}$ solution 0.1 mol L-1 up to $\mathrm{pH}=8.7$.

Lanthanide chlorides were prepared from the corresponding metal oxides (except for cerium) by treatment with hydrochloric acid solution. The resulting solutions were evaporated to near dryness, the residues were again dissolved in distilled water, transferred to a volumetric flask and diluted in order to obtain ca. $0.1 \mathrm{~mol} \mathrm{~L}^{-1}$ solutions, whose $\mathrm{pH}$ were adjusted to 5.5 by adding diluted sodium hydroxide or hydrochloric acid solutions. Cerium (III) was used as its nitrate and ca $0.1 \mathrm{~mol} \mathrm{~L}^{-}$ 
${ }^{1}$ aqueous solution of this ion was prepared by direct weighing of the salt.

The solid state compounds were prepared by adding slowly, under continuous stirring, the solution of the ligand to the respective metal chloride or nitrate solutions, until total precipitation of the metal ions. The precipitates were washed with distilled water until elimination of the chloride (or nitrate) ions, filtered through and dried on Whatman $n^{\circ} 42$ filter paper, and kept in a desiccator over anhydrous calcium chloride.

In the solid state compounds, ligand and metal ion contents were determined from TG curves. The metal ions were also determined by complexometric titrations with standard EDTA solution, using xylenol orange as indicador [2122].

X-ray powder patterns were obtained by using a SIEMENS D-5000 X-ray diffractometer employing $\mathrm{Cu}$ Ka radiation $(1=1.541 \AA)$ and setting of $40 \mathrm{kV}$ and $20 \mathrm{~mA}$.

Infrared spectra for $\mathrm{Na}-3-\mathrm{MeO}-\mathrm{Bz}$ as well as for its metal ion compounds were run on a Nicolet model Impact 400 FT-IR Instrument, within the $4000-400 \mathrm{~cm}^{-1}$ range. The solid samples were pressed into $\mathrm{KBr}$ pallets.

The TG curves were obtained by using a Mettler TA-4000 thermal analysis system, with air flowing at $100 \mathrm{~mL} \mathrm{~min}^{-1}$, a heating rate of $20^{\circ} \mathrm{C} \mathrm{min}^{-}$ ${ }^{1}$ and with samples weighing about $7 \mathrm{mg}$. An alumina crucible was used to obtain the TG curve.

The DSC curves were obtained with a thermal analysis system model DSCQ10 from TA Instruments. The purge gas was an air flow of 50 $\mathrm{mL} \mathrm{min}{ }^{-1}$. A heating rate was $20{ }^{\circ} \mathrm{C} \mathrm{min}{ }^{-1}$ was adopted with samples weighing about $5 \mathrm{mg}$. Aluminium crucibles with perforated cover were used for recording the DSC curves.

\section{Results and discussion}

The analytical and thermoanalytical (TG) results are shown in Table 1 . These results establish the stoichiometry of these compounds, which are in agreement with the general formula, $\mathrm{Ln}(3-\mathrm{MeO}-\mathrm{Bz})_{3} \cdot \mathrm{nH}_{2} \mathrm{O}$, where $\mathrm{Ln}$ represents lighter trivalent lanthanides ( $\mathrm{La}-\mathrm{Sm}), 3-\mathrm{MeO}-\mathrm{Bz}$ is 3methoxybenzoate and $\mathrm{n}=2(\mathrm{La}, \mathrm{Pr}, \mathrm{Nd}, \mathrm{Sm}), 2.5$ (Ce).

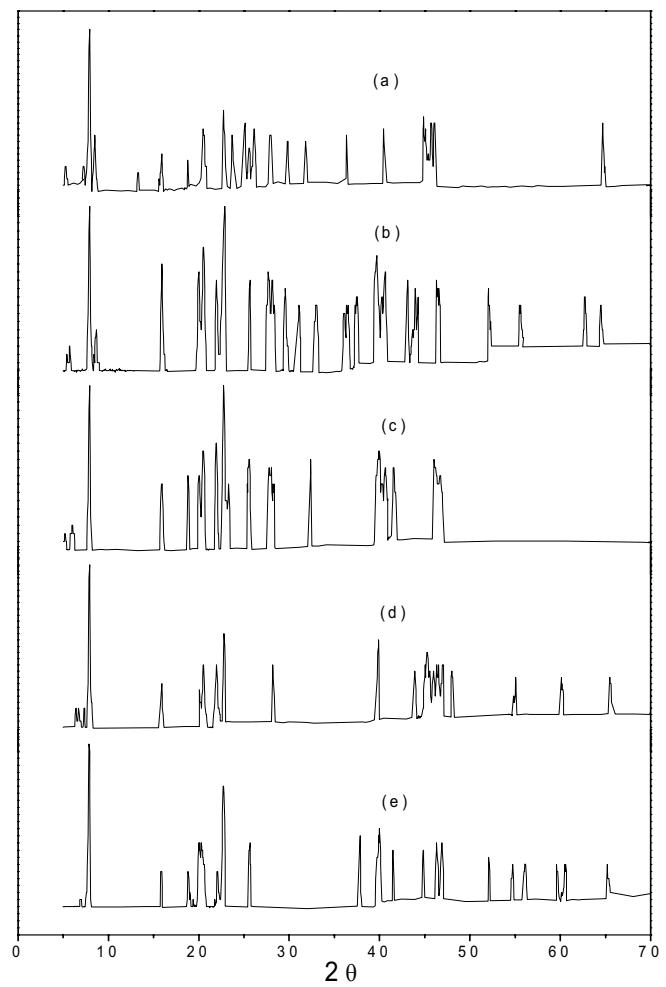

Figure 1: X-ray powder diffraction patterns of the compounds: (a) $\mathrm{La}(\mathrm{L})_{3} \cdot 2 \mathrm{H}_{2} \mathrm{O}$, (b) $\mathrm{Ce}(\mathrm{L})_{3} .2 .5 \mathrm{H}_{2} \mathrm{O},(\mathrm{c}) \operatorname{Pr}(\mathrm{L})_{3} .2 \mathrm{H}_{2} \mathrm{O},(\mathrm{d}) \mathrm{Nd}(\mathrm{L})_{3} .2 \mathrm{H}_{2} \mathrm{O}$ and (e) $\mathrm{Sm}(\mathrm{L})_{3} .2 \mathrm{H}_{2} \mathrm{O}$. ( $\mathrm{L}=3$-methoxybenzoate).

Table1.Analytical and thermoanalytical (TG) data of the compounds.

\begin{tabular}{|c|c|c|c|c|c|c|c|c|}
\hline \multirow{2}{*}{ Compound } & \multicolumn{3}{|c|}{ Metal (\%) } & \multicolumn{2}{|c|}{ Loss $(\%)$} & \multicolumn{2}{|c|}{ Water (\%) } & \multirow{2}{*}{ Residue } \\
\hline & Calcd. & TG & EDTA & Calcd. & TG & Calcd. & TG & \\
\hline $\mathrm{La}(\mathrm{L})_{3} \cdot 2 \mathrm{H}_{2} \mathrm{O}$ & 22.11 & 21.98 & 22.67 & 68.34 & 68.38 & 5.74 & 5.93 & $\mathrm{La}_{2} \mathrm{O}_{3}$ \\
\hline $\mathrm{Ce}(\mathrm{L})_{3} \cdot 2.5 \mathrm{H}_{2} \mathrm{O}$ & 21.94 & 21.99 & 22.05 & 65.99 & 66.25 & 7.05 & 6.71 & $\mathrm{CeO}_{2}$ \\
\hline $\operatorname{Pr}(\mathrm{L})_{3} \cdot 2 \mathrm{H}_{2} \mathrm{O}$ & 22.35 & 22.30 & 21.63 & 67.28 & 67.02 & 5.72 & 6.12 & $\mathrm{Pr}_{6} \mathrm{O}_{11}$ \\
\hline $\mathrm{Nd}(\mathrm{L})_{3} \cdot 2 \mathrm{H}_{2} \mathrm{O}$ & 22.76 & 22.76 & 22.90 & 67.77 & 67.63 & 5.69 & 5.95 & $\mathrm{Nd}_{2} \mathrm{O}_{3}$ \\
\hline $\mathrm{Sm}(\mathrm{L})_{3} \cdot 2 \mathrm{H}_{2} \mathrm{O}$ & 23.50 & 24.10 & 24.31 & 67.12 & 67.07 & 5.63 & 5.17 & $\mathrm{Sm}_{2} \mathrm{O}_{3}$ \\
\hline
\end{tabular}

L means 3-metoxybenzoate 
Infrared spectroscopic data on 3methoxybenzoate sodium salt and its compounds with ligther trivalent lanthanides are shown in Table 2 . The investigation was focused mainly within the $1700-1400 \mathrm{~cm}^{-1}$ range, because this region is potencially most informative to assign coordination sites. In the sodium 3methoxybenzoate, strong bands located at 1568 $\mathrm{cm}^{-1}$ and $1400 \mathrm{~cm}^{-1}$ are attributed to the antisymmetrical and symmetrical frequencies of the carboxylate groups, respectively $[23,24]$. In the compounds considered in this work, analysis of the frequencies of the $n_{\text {as }}$ and $n_{\text {sym }}\left(\mathrm{COO}^{-}\right)$bands shows that the lanthanides are linked to the carboxylate group by a bidentate bond with an incomplete equalization of bond lengths in the carboxylate anion; this is in agreement with the literature [5,11-13].

The TG curves of the compounds are shown in Fig. 2. These curves show mass losses in two $(\mathrm{Ce})$, three $(\mathrm{Pr}, \mathrm{Sm})$ or four $(\mathrm{La}, \mathrm{Nd})$ steps. In all the TG curves, the first mass loss between 50 and $100{ }^{\circ} \mathrm{C}$ is attributed to dehydration, which occurs in a single step. Once dehydrated, the anhydrous compounds are stable up to $270^{\circ} \mathrm{C}(\mathrm{Ce})$, $330^{\circ} \mathrm{C}(\mathrm{La}, \mathrm{Nd}, \mathrm{Sm})$ and $355^{\circ} \mathrm{C}(\mathrm{Pr})$ and above these temperatures the TG curves show that the thermal decomposition is characteristic for each compound.

For the lanthanum compound, Fig. 2 (a) the first mass loss is due to dehydration, with loss of $2 \mathrm{H}_{2} \mathrm{O}$ (calcd. $=5.74 \%, \mathrm{TG}=5.93 \%$ ). The thermal decomposition of the anhydrous compound occurs in three steps between 330 and $750{ }^{\circ} \mathrm{C}$, with the two first ones a fast processes and losses of 29.46 and $28.90 \%$, respectively. In the last step the mass loss occurs through a slow process with formation of lanthanum oxide, $\mathrm{La}_{2} \mathrm{O}_{3}$ as final residue.

For the cerium compound, Fig. 2 (b) the first mass loss is due to dehydration with loss of $2.5 \mathrm{H}_{2} \mathrm{O}$ (calcd. $=7.05 \%, \mathrm{TG}=6.71 \%$ ). The thermal decomposition of the anhydrous compound occurs in a single step between 270 and $570^{\circ} \mathrm{C}$, with loss of $66.25 \%$. The lower thermal stability of the cerium compound, as compared with the other compounds is undoubtedly related to the exothermic oxidation

Table 2. Spectroscopic data for sodium 3-methoxybenzoate and compounds with lighter trivalent lanthanides.

\begin{tabular}{lcccc}
\hline \multicolumn{1}{c}{ Compound } & $\begin{array}{c}v_{(\mathrm{O}-\mathrm{H})} \mathrm{H}_{2} \mathrm{O} \\
\left(\mathrm{cm}^{-1}\right)\end{array}$ & $\begin{array}{c}v_{\mathrm{as}\left(\mathrm{COO}^{-}\right)} \\
\left(\mathrm{cm}^{-1}\right)\end{array}$ & $\begin{array}{c}v_{\mathrm{sym}\left(\mathrm{COO}^{-}\right)} \\
\left(\mathrm{cm}^{-1}\right)\end{array}$ & $\begin{array}{c}\Delta v_{\left(\mathrm{vas}^{-} \mathrm{v}_{\mathrm{sym}}\right)} \\
\left(\mathrm{cm}^{-1}\right)\end{array}$ \\
\hline $\mathrm{Na}(3-\mathrm{MeO}-\mathrm{Bz})$ & - & $1568_{\mathrm{s}}$ & $1402_{\mathrm{s}}$ & 168 \\
$\mathrm{La}(3-\mathrm{MeO}-\mathrm{Bz})_{3} \cdot 2 \mathrm{H}_{2} \mathrm{O}$ & $3487_{\mathrm{br}}$ & $1529_{\mathrm{s}}$ & $1406_{\mathrm{s}}$ & 123 \\
$\mathrm{Ce}(3-\mathrm{MeO}-$ & $3492_{\mathrm{br}}$ & $1525_{\mathrm{s}}$ & $1400_{\mathrm{s}}$ & 125 \\
$\mathrm{Bz})_{3} \cdot 2 \cdot 5 \mathrm{H}_{2} \mathrm{O}$ & & $1529_{\mathrm{s}}$ & $1406_{\mathrm{s}}$ & 123 \\
$\mathrm{Pr}(3-\mathrm{MeO}-\mathrm{Bz})_{3} \cdot 2 \mathrm{H}_{2} \mathrm{O}$ & $3489_{\mathrm{br}}$ & $1529_{\mathrm{s}}$ & $1409_{\mathrm{s}}$ & 120 \\
$\mathrm{Nd}(3-\mathrm{MeO}-\mathrm{Bz})_{3} \cdot 2 \mathrm{H}_{2} \mathrm{O}$ & $3501_{\mathrm{br}}$ & & & 120 \\
$\mathrm{Sm}(3-\mathrm{MeO}-$ & $3510_{\mathrm{br}}$ & $1529_{\mathrm{s}}$ & $1409_{\mathrm{s}}$ & \\
$\mathrm{Bz})_{3} \cdot 2 \mathrm{H}_{2} \mathrm{O}$ & & &
\end{tabular}

br: broad; s = strong; 3-MeO-Bz = 3-metoxybenzoate

$v_{(\mathrm{O}-\mathrm{H})}$ : hydroxyl group stretching frequency; $v_{\mathrm{sym}\left(\mathrm{COO}^{-}\right)}$and $v_{\mathrm{as}\left(\mathrm{COO}^{-}\right)}=$symmetrical and antisymmetrical vibrations of the $\mathrm{COO}^{-}$structure. 
reaction that results in the formation of cerium (IV) oxide.

In the praseodymium compound, Fig. 2 (c) the first mass loss is due to the dehydration with loss of $2 \mathrm{H}_{2} \mathrm{O}$ (calcd. $=5.72 \%, \mathrm{TG}=6.12 \%$ ). The thermal decomposition of the anhydrous compound occurs in two steps between $355^{\circ} \mathrm{C}$ and $720^{\circ} \mathrm{C}$. The mass loss up to $440{ }^{\circ} \mathrm{C}$ occurs through a fast process followed by a slow one with losses of 29.36 and $37.66 \%$, respectively and with formation of praseodymium oxide, $\operatorname{Pr}_{6} \mathrm{O}_{11}$ as final residue.

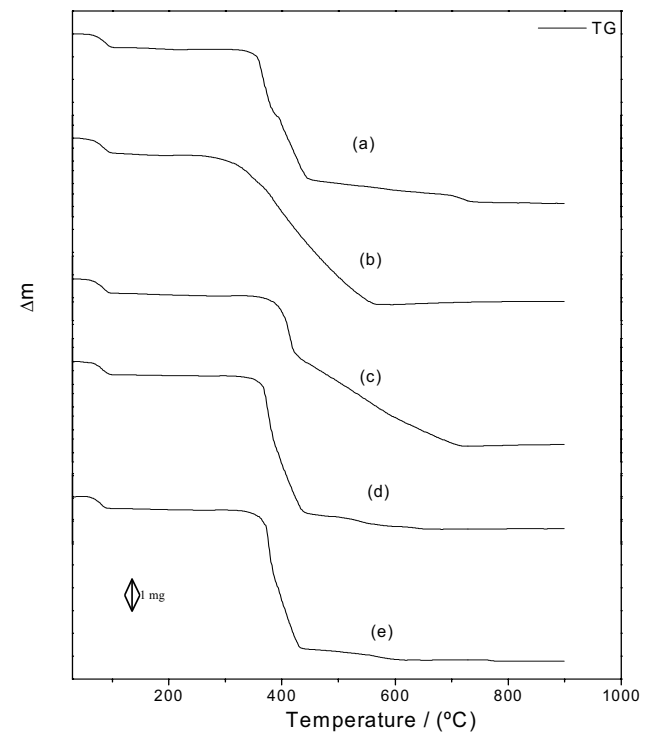

Figure 2: TG curves of the compounds: (a) $\mathrm{La}(\mathrm{L})_{3} \cdot 2 \mathrm{H}_{2} \mathrm{O}(\mathrm{m}=7.090 \mathrm{mg})$, (b) $\mathrm{Ce}(\mathrm{L})_{3} \cdot 2.5 \mathrm{H}_{2} \mathrm{O}(\mathrm{m}=7.020 \mathrm{mg}),(\mathrm{c}) \operatorname{Pr}(\mathrm{L})_{3} \cdot 2 \mathrm{H}_{2} \mathrm{O}(\mathrm{m}=6.780 \mathrm{mg}),(\mathrm{d}) \mathrm{Nd}(\mathrm{L})_{3} \cdot 2 \mathrm{H}_{2} \mathrm{O}$ $(\mathrm{m}=6.960 \mathrm{mg})$ and $(\mathrm{e}) \mathrm{Sm}(\mathrm{L})_{3} \cdot 2 \mathrm{H}_{2} \mathrm{O}(\mathrm{m}=7.030 \mathrm{mg})$. heating rate: $20^{\circ} \mathrm{min}^{-1}$; air flow: $100 \mathrm{~mL} \mathrm{~min}^{-1}$. $\mathrm{L}=3$-methoxybenzoate.

In the neodymium compound, Fig. 2 (d) the first mass loss is attributed to dehydration with loss of $2 \mathrm{H}_{2} \mathrm{O}$ (calcd. $=5.69 \%, \mathrm{TG}=5.95 \%$ ). The thermal decomposition of the anhydrous compound occurs in three steps between 330 and $655^{\circ} \mathrm{C}$. The first mass loss up to $440^{\circ} \mathrm{C}$, also occurs through a fast process, followed by two slow processes with losses of $60.54,6.00$ and $1.09 \%$, respectively resulting in the formation of neodymium oxide, $\mathrm{Nd}_{2} \mathrm{O}_{3}$, as final residue.

For the samarium compound, Fig. 2 (e) the first mass loss is due to dehydration with loss of 2 $\mathrm{H}_{2} \mathrm{O}$ (calcd. $=5.63 \%, \mathrm{TG}=5.17 \%$ ). The thermal decomposition of the anhydrous compound occurs in two steps between 330 and $620^{\circ} \mathrm{C}$. The first mass loss up to $435{ }^{\circ} \mathrm{C}$ occurs through a fast process followed by a slow process with losses of 61.70 and $5.37 \%$, respectively, leading to formation of samarium oxide, $\mathrm{Sm}_{2} \mathrm{O}_{3}$ as final residue.

The DSC curves of the compounds are shown in Fig. 3. These curves show endothermic and exothermic events that are in agreement with the mass losses observed in the TG curves and endothermic peaks due to crystalline phase transition. The endothermic peak at $115^{\circ} \mathrm{C}(\mathrm{La})$, $117^{\circ} \mathrm{C}(\mathrm{Ce}), 107^{\circ} \mathrm{C}(\mathrm{Pr}), 114^{\circ} \mathrm{C}(\mathrm{Nd})$ and $106^{\circ} \mathrm{C}(\mathrm{Sm})$ is due to dehydration. The dehydration enthalpies found for the lanthanum to samarium compounds were: $112.2,105.4,106.8,95.5$ and $93.3 \mathrm{~kJ} \mathrm{~mol}^{-1}$.

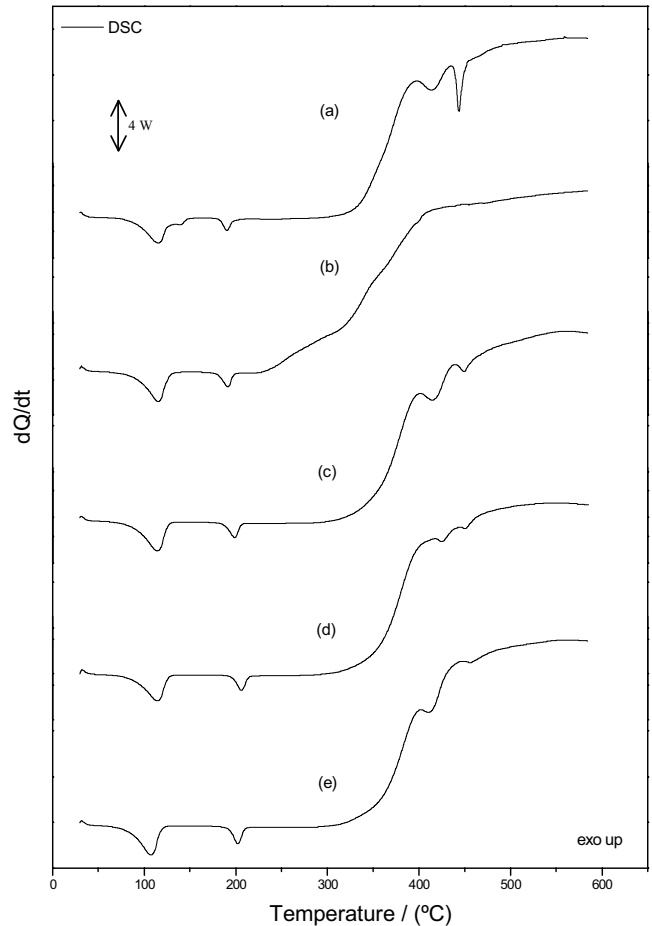

Figure 3: DSC curves of the compounds: (a) $\mathrm{La}(\mathrm{L})_{3} .2 \mathrm{H}_{2} \mathrm{O}(\mathrm{m}=4.906 \mathrm{mg})$, (b) $\mathrm{Ce}(\mathrm{L})_{3} \cdot 2.5 \mathrm{H}_{2} \mathrm{O}(\mathrm{m}=5.091 \mathrm{mg})$, (c) $\operatorname{Pr}(\mathrm{L})_{3} \cdot 2 \mathrm{H}_{2} \mathrm{O}(\mathrm{m}=5.227 \mathrm{mg})$, (d) $\mathrm{Nd}(\mathrm{L})_{3} .2 \mathrm{H}_{2} \mathrm{O}(\mathrm{m}=5.052 \mathrm{mg})$ and $(\mathrm{e}) \mathrm{Sm}(\mathrm{L})_{3} .2 \mathrm{H}_{2} \mathrm{O}(\mathrm{m}=5.255 \mathrm{mg})$. heating rate: $20^{\circ} \mathrm{min}^{-1}$; air flow: $50 \mathrm{mLmin}^{-1}$. L = 3-methoxybenzoate.

The broad exothermic event observed for all compounds, except the cerium, between 325 and temperature higher than $600{ }^{\circ} \mathrm{C}$ without the appearance of definitive peaks are due to the thermal decomposition of the anhydrous compounds, where the oxidation of the organic matter takes place in consecutive and/or overlapping steps. For the cerium compound the exothermic event between 225 and temperature higher than $600{ }^{\circ} \mathrm{C}$, 
the oxidation of the organic matter takes place in a single step.

The endothermic peak at $190^{\circ} \mathrm{C}(\mathrm{La}), 193$ ${ }^{\circ} \mathrm{C}(\mathrm{Ce}), 193{ }^{\circ} \mathrm{C}(\mathrm{Pr}), 205^{\circ} \mathrm{C}(\mathrm{Nd})$ and $201^{\circ} \mathrm{C}(\mathrm{Sm})$ are due to crystalline phase transition. The crystalline phase transition enthalpies found for the lanthanum to samarium compounds were: 14.9, $22.1,23.8,23.8$ and $24.4 \mathrm{~kJ} \mathrm{~mol}^{-1}$ respectively.

\section{Conclusion}

From analytical and thermoanalytical (TG) results a general formula could be established for these compounds in the solid state.

The X-ray powder patterns pointed out that the synthesized compounds have a crystalline structure without evidence for formation of isomorphous compounds.
The infrared spectroscopic data suggest that the $3-\mathrm{MeO}-\mathrm{Bz}$ acts as a bidentate ligand toward the metal ions considered in this work.

The TG and DSC curves provided previously unreported information about the thermal behaviour and thermal decomposition of these compounds.

Received 11 April 2007

Accepted 16 May 2007

\section{Acknowledgements}

The authors thank FAPESP (Proc. 90/29334), CNPq and CAPES Foundations (Brazil) for financial support.

P. R. Dametto, A. B. Siqueira, C. T. Carvalho, M. Ionashiro ${ }^{1}$.Sintese, caracterizacao e estudo térmico dos 3metoxibenzoato de lantanídeos mais leves no estado sólido.

Resumo: Compostos do tipo Ln-3-MeO-Bz foram sintetizados no estado sólido, em que Ln representa os íons trivalentes $\mathrm{La}, \mathrm{Ce}, \mathrm{Pr}, \mathrm{Nd}$ e Sm, e 3-MeO-Bz é o ânion 3-metoxibenzoato. Esses compostos foram caracterizados, utilizando-se as técnicas de difração de raios X pelo método do pó, espectroscopia na região do infravermelho, complexometria, e seu comportamento térmico foi avaliado usando termogravimetria (TG) e calorimetria exploratória diferencial (DSC). Os resultados forneceram informações com respeito a estequiometria, desidratação, transformação polimórfica, comportamento e decomposição térmica desses compostos.

Palavras-chave: lantanídeos leves; 3-metoxibenzoato; caracterização; comportamento térmico.

\section{References}

[1] S. J. Yun, S. K. Kang, S. S. Yun, Thermochim. Acta 331(1) (1999) 13.

[2] Z. M. Wang, L. J. van de Burgt, G. R. Choppin, Inorg. Chim. Acta 293(2) (1999) 167.

[3] N. Arnaud, J. Georges, Analyst 125(8) (2000) 1487.

$4]$ G. R. Choppin, Q. Liu, E. N. Rizkalla, Inorg. Chim. Acta 145(2) (1988) 309.

[5] A. W. H. Lam, W. T. Wang, S. Gao, G. Wen, X. X. Zhang, Eu. J. Inorg. Chem. 1 (2003) 149.

[6] G. N. Makushova, S. B. Pirkes, E. Y. Levina, Zh. Neorg. Khim. 30(9) (1985) 2273.

[7] W. Ferenc, B. Bocian, J. Therm. Anal. Cal. 74(2) (2003) 521.

[8] W. Brzyska, W. Ozga, J. Thermal Anal. Cal. 78(3) (2004) 999.

[9] W. Ferenc, A. Walkow-Dziewulska, B. Bocian, J. Therm. Anal. Cal. 79(1) (2005) 145.

[10] A. Kula, J. Therm. Anal. Cal. 81(2) (2005) 381.

[11] E. C. Rodrigues, A. B. Siqueira, E. Y. Ionashiro, G. Bannach, M. Ionashiro, Ecl. Quim. 31(1) (2006) 21

[12] E. C. Rodrigues, A. B. Siqueira, E. Y. Ionashiro, G. Bannach, M. Ionashiro, Thermochim. Acta 451(1-2) (2006) 149.

[13] W. Lewandowski, J. Molec. Struct. 101(1-2) (1983) 93.

[14] W. Lewandowski, H. Barauska, J. Raman Spectroscopy 17(1) (1986) 17.
[15] T. Glowiak, H. Koslowski, L. Strinna Erre, B. Gulinati, G. Micera, A. Pozzi, S. Brunni, J. Coord. Chem. 25(1) (1992) 75.

[16] W. Brzyska, S. Karasinshi, J. Therm. Anal. 39(4) (1993) 429.

[17] E. C. Rodrigues, A. B. Siqueira, E. Y. Ionashiro, G. Bannach, M. Ionashiro, J. Therm. Anal. Cal. 79(2) (2005) 323.

[18] A. C. Vallejo, A. B. Siqueira, E. C. Rodrigues, E.Y. Ionashiro, G. Bannach, M. Ionashiro, Ecl. Quim. 30(3) (2005) 7.

[19] C. T. Carvalho, A. B. Siqueira, E. C. Rodrigues, M. Ionashiro, Ecl. Quim. 30(4) (2005) 19.

[20] A. B. Siqueira, E. Y. Ionashiro, C. T. Carvalho, G. Bannach, E. C. Rodrigues, M. Ionashiro, Quim. Nova 30(2) (2007) 318.

[21] H. A. Flaschka, EDTA Titrations, Pergamon Press, Oxford, 1964

[22] M. Ionashiro, C. A. F. Graner, J. Zuanon Netto, Ecl. Quim. 8 (1983) 29.

[23] G. Sócrates, Infrared Characteristic Group Frequencies, Wiley, New York, 2nd edn., 1994, pp. 91 and 236-237.

[24] R. M. Silverstein, F. X. Webster, Spectrometric Identification of Organic Compounds, Wiley, New York, 6th edn., 1998, pp. 92, 93, 96 and 97. 